\title{
ANALISIS DETERMINASI PERTUMBUHAN EKONOMI PROVINSI JAMBI
}

\author{
Ali Fahmi \\ STIE Muhahammadiyah Jambi \\ E-mail: alifahmi1969@yahoo.com
}

\begin{abstract}
This research aims to analyze the effect of government spending, investment of foreign capital investment, capital investment In Land and labor against growth of Jambi province during the 2004-2015. This research using Time Series data with regression analysis "Ordinary Least Square (OLS) wear EViews 8. The findings from this research indicate that Labor become the most variable gives a positive impact against the next economic growth, government spending and investment, while investing PMDN PMA gives negative impact on The Economic Growth Of The Province Of Jambi. PMA investment posit no impact and no signikan against economic growth this is not prevalent, but it is possible the investment PMA in Jambi province is relatively small and still no impact in the absorption of the local Workforce. Menyikapai is an effort to boost the Economic growth of the Province of Jambi then needed a special business development policies should be directed at the activities that are labor-intensive to absorb labor as much as possible.
\end{abstract}

Keywords: economic growth, government spending, PMA, the PMDN, and labor.

\section{PENDAHULUAN}

Pertumbuhan ekonomi adalah proses perubahan kondisi perekonomian suatu Negara secara berkesinambungan menuju keadaan yang lebih baik selama periode tertentu. Sementara perkembangan ekonomi menimbukan dua efek penting, yaitu kemakmuran atau taraf hidup masyarakat meningkat, menciptakan kesempatan kerja baru, dan dapat juga memacu pertambahan penduduk yang semakin tinggi. Pembangunan ekonomi daerah mempunyai tujuan utama untuk meningkatkan jumlah dan jenis peluang kerja untuk masyarakat daerah. Dalam upaya untuk mencapai tujuan tersebut, pemerintah daerah dan masyarakatnya harus secara bersama-sama mengambil inisiatif pembangunan daerah. Oleh karena itu, pemerintah daerah beserta partisipasi masyarakatnya dan dengan menggunakan sumber daya yang ada harus mampu menaksir potensi sumber daya yang diperlukan untuk merancang dan membangun perekonomian daerah (Arsyad, 2004). Pembangunan ekonomi daerah merupakan bagian integral dari pembangunan ekonomi nasional yang dilaksanakan berdasarkan prinsip otonomi daerah dan salah satu indikator keberhasilan pelaksanaan pembangunan yang dapat dijadikan tolok ukur secara makro adalah pertumbuhan ekonomi.

Malthus dalam Nanga (2005:273) bahwa jika penduduk bertambah lebih cepat daripada kemampuan pertumbuhan ekonomi maka pertumbuhan penduduk harus dikendalikan atau dikontrol, sebab kalau tidak akan menyebabkan pengangguran. Harrod-Domar dalam (Adisasmita,2013:59) memiliki sisi pandangan berbeda dimana penanaman modal atau investasi mempunyai fungsi ganda dalam perekonomian, yaitu untuk mempertinggi pengeluaran masyarakat dan memacu pertumbuhan ekonomi. Dalam analisis Neo Klasik, permintaan 
masyarakat tidak menentukan lajunya pertumbuhan, pertumbuhan ekonomi tergantung pada pertambahan dalam penawaran faktor-faktor produksi dan tingkat kemajuan teknologi. Output barang atau jasa yang dihasilkan oleh suatu perekonomian bergantung pada kuantitas input yang tersedia, seperti capital dan tenaga kerja, dan produktivitas dari input tersebut. Era desentralisasi dan otonomi daerah dapat meningkatkan kapasitas fiskal agar mampu memenuhi kebutuhan fiskal sehingga tidak mengalami kesenjangan fiskal.Salah satu upaya untuk meningkatkan penerimaan Pendapatan Asli Daerah melalui belanja modal. Pertumbuhan ekonomi di Provinsi Jambi dalam empat tahun terakhir pada tahun 2011 sebesar 7,86 persen, pada tahun 2012 sebesar 7,03 persen, pada tahun 2013 sebesar 6,84, pada tahun 2014sebesar 7,35 \%, dan menurun pada tahun 2015 sebesar 4,4 \%.Pertumbuhan ekonomi Provinsi Jambi yang paling tinggi berada pada tahun 2011 sebesar 7,8\% dan pertumbuhan ekonomi Provinsi Jambi yang terendah berada pada tahun 2015 sebesar $4,5 \%$.

Pertumbuhan ekonomi Indonesia memang cukup tinggi, akan tetapi menurut Adi (2011) penyerapan tenaga kerja relatif rendah, dimana setiap satu persen pertumbuhan ekonomi Indonesia hanya menyerap 250 ribu tenaga kerja baru. Meningkatkan pertumbuhan ekonomi investasi juga diharapkan akan meningkatkan pertumbuhan ekonomi di Provinsi Jambi. Menurut Nurkse dalam Adisasmita (2013:115) lingkaran setan di negara berkembang dapat digunting (dipatahkan) melalui pembentukan modal. Penciptaan iklim investasi yang lebih menarik minat investor dikembangkan melalui penyediaan sarana dan prasarana yang menunjang kegiatan ekonomi, jaminan kepastian hukum dan peraturan perundang-undangan yang berlaku dapat mendukung dan memberikan kemudahan bagi investasi. Pengeluaran Pemerintah, tingkat investasi baik PMA dan PMDN, dan Tenaga kerja merupakan sebagai penggerak dan pelaksana daripada pembangunan di suatu daerah dengan demikian diharapkan menjadi pendorong dalam peningkatan pertumbuhan ekonomi di Provinsi Jambi.

\section{METODE}

Penelitian ini kualitatif kausalitas untuk menguji pengaruh Pengeluaran Pemerintah, Investasi PMA, Investasi PMDN dan Tenaga Kerja terhadap Pertumbuhan ekonomi di Provinsi Jambi periode 2004-2015. Analisis ini digunakan untuk mengetahui arah hubungan antara variabel independen dengan variabel dependen dan untuk memprediksi nilai dari variabel dependen dan nilai variabel independen. Untuk menjawab tujuan pertama penelitian digunakan alat analisis deskriftif, untuk tujuan kedua yaitu Pengaruh; Pengeluran Pemerintah,PMA, PMDN dan Tenaga Kerja terhadap Pertumbuhan Ekonomi dengan menggunakan metode regresi kuadrat terkecil atau Ordinary Least Square (OLS)

Variabel yang digunakan dalam penelitian ini adalah variabel bebas dan variabel terikat menurut Narimawati (2010:31)

Variabel Dependen :

Pertumbuhan ekonomi yaitu tingkat pertumbuhan ekonomi provinsi Jambi yang diproksikan dengan PDRB atas dasar harga konstan dan dinyatakan dalam juta rupiah.

Variabel Independen

1. Pengeluaran pemerintah (PP) adalah nilai belanja modal dalam PDRB dengan Harga Konstan Provinsi Jambi yang dinyatakan dalam juta rupiah. 
2. PMA adalah keseluruhan Penanaman Modal Asing yang telah disetujui dan telah terealisasi di Provinsi Jambi yang dinyatakan dalam juta rupiah.

3. PMDN adalah keseluruhan Penanaman Modal Dalam Negeri yang telah disetujui dan telah terealisasi di Provinsi Jambi yang dinyatakan dalam juta rupiah.

4. Tenaga Kerja (TK) adalah jumlah penduduk usia kerja umur 15 tahun sampai dengan 64 tahun yang sudah mempunyai pekerjaan di Provinsi Jambi dalam jiwa atau orang.

\section{HASIL}

\section{Pertumbuhan Ekonomi}

Pertumbuhan ekonomi adalah salah satu indikator penting dalam melakukan analisis tentang pembangunan ekonomi yang terjadi pada suatu negara.Pertumbuhan ekonomi menunjukkan sejauh mana aktivitas perekomian akan menghasilkan tambahan pendapatan masyarakat pada suatu periode tertentu. Teori Pertumbuhan Ekonomi Neo Klasik menyatakan pertumbuhan ekonomi bergantung pada perkembangan faktor-faktor produksi yaitu modal, tenaga kerja dan teknologi. Menurut Smith dalam Adisasmita (2013:58) perkembangan penduduk akan mendorong pembangunan ekonomi, penduduk yang bertambah akan memperluas pasar dan perluasan pasar meningkatkan spesialisasi dalam perekonomian yang akan meningkatkan kegiatan ekonomi. Pengembangan spesilisasi dan pembagian kerja diantara tenaga kerja dan mendorong perkembangan teknologi.

PDRB atas dasar harga konstan adalah menunjukan laju pertumbuhan ekonomi secara keseluruhan/ setiap sektor ekonomi dari tahun ke tahun, untuk melihat pertumbuhan ekonomi Provinsi Jambi dapat kita lihat pada Tabel 1 Laju pertumbuhan ekonomi Provinsi Jambi dalam kurun waktu 2004-2015 rata-rata 6,59 dengan pola berfluktuatif, pada tahun pada tahun 2011 pertubuhan tertinggi 7,86 dan terendah pada tahun 2015 sebesar 4,21\%.

Tabel 1

Pertumbuhan Ekonomi Di Provinsi Jambi Tahun 2004 - 2015.

\begin{tabular}{crr}
\hline Tahun & PDRB ADHK 2000 (Juta Rupiah) & Pertumbuhan Ekonomi (\%) \\
\hline 2004 & 11.953 .885 & - \\
2005 & 12.619 .973 & 5,57 \\
2006 & 13.363 .620 & 5,89 \\
2007 & 14.275 .161 & 6,82 \\
2008 & 15.279 .770 & 7,04 \\
2009 & 16.274 .907 & 6,51 \\
2010 & 17.470 .653 & 7,35 \\
2011 & 18.843 .846 & 7,86 \\
2012 & 20.168 .569 & 7,03 \\
2013 & 21.548 .099 & 6,84 \\
2014 & 23.131 .884 & 7,35 \\
2015 & 24.105 .736 & 4,21 \\
Rata-Rata & $\mathbf{1 7 . 4 1 9 . 6 7 5}$ & $\mathbf{6 , 5 9}$ \\
\hline
\end{tabular}

Sumber : Bagian Perekonomian Setda dan Biro Keuangan Provinsi Jambi 2016 


\section{Hubungan antara Pengeluaran Pemerintah dengan Pertumbuhan Ekonomi}

Pengeluaran pemerintah mencerminkan kebijakan pemerintah untuk membeli barang dan jasa, pengeluaran pemerintah mencerminkan biaya yang harus dikeluarkan oleh pemerintah untuk melaksanakan kebijakan tersebut. Teori Peacock dan Wiseman menyatakan perkembangan ekonomi menyebabkan pemungutan pajak yang semakin meningkat walaupun tarif pajak tidak berubah dan meningkatnya penerimaan pajak menyebabkan pengeluaran pemerintah juga semakin meningkat, oleh karena itu dalam keadaan normal meningkatnya pendapatan nasional menyebabkan penerimaan pemerintah yang semakin besar, begitu juga dengan pengeluaran pemerintah menjadi semakin besar (Mangkoesoebroto, 1993). Mankiw (2006) menyebutkan bahwa pendapatan total perekonomian dalam jangka pendek sangat ditentukan oleh keinginan rumah tangga, perusahaan dan pemerintah untuk membelanjakan pendapatannya.. Kenaikan pengeluaran yang direncanakan akan menyebabkan peningkatan permintaan agregat. Permintaan agregat akan mendorong produksi barang dan jasa yang akan menyebabkan pendapatan juga akan meningkat. Tabel 2 dibawah dapat tergambarkan perkembangan pengeluaran pemerintah Provinsi Jambi selama periode 2004-2015 :

Tabel 2

Perkembangan Pengeluaran Pemerintah Provinsi Jambi Tahun 2004-2015

\begin{tabular}{crr}
\hline Tahun & Pengeluaran Pemerintah (Juta Rupiah) & Perkembangan (\%) \\
\hline 2004 & $581.432,85$ & - \\
2005 & $642.833,02$ & 10,56 \\
2006 & $963.238,88$ & 49,84 \\
2007 & $980.161,41$ & 1,76 \\
2008 & $1.206 .213,28$ & 23,06 \\
2009 & $1.479 .088,14$ & 22,62 \\
2010 & $1.434 .178,41$ & $-3,04$ \\
2011 & $1.682 .109,61$ & 17,29 \\
2012 & $2.531 .598,00$ & 50,50 \\
2013 & $3.010 .741,17$ & 18,93 \\
2014 & $3.265 .329,75$ & 8,46 \\
2015 & $3.513 .160,76$ & 7,59 \\
Rata-rata & $\mathbf{1 . 7 7 4 . 1 7 4}$ & $\mathbf{1 8 , 8 7}$ \\
\hline
\end{tabular}

Sumber : BPS Provinsi Jambi Tahun 2016, data diolah

\section{Hubungan antara Investasi dengan Pertumbuhan Ekonomi}

Penanaman Modal Asing (PMA) merupakan bentuk investasi dengan jalan membangun, membeli total atau mengakuisisi perusahaan.Penanaman Modal di Indonesia diatur dalam Undang-Undang Nomor 25 tahun 2007 tentang Penanaman Modal.Penanaman Modal Asing (PMA) lebih banyak mempunyai kelebihan diantaranya sifatnya jangka panjang, banyak memberikan adil (andil) dalam alih teknologi, alih keterampilan manajemen, membuka lapangan kerja baru. Lapangan kerja ini, sangat penting bagi negara sedang berkembang mengingat terbatasnya kemampuan pemerintah untuk penyediaan lapangan kerja. Menurut Deviyantini pada tahun 2012 melakukan penelitian dampak Foreign Direct Investment (FDI) terhadap pertumbuhan ekonomi nasional.Untuk kasus Negara maju, hasil penelitian tersebut menunjukan bahwa FDI merupakan faktor 
yang mempunyai pengaruh positif bagi pertumbuhan ekonomi.Menurut kajian Aitken dan Harrison (1999) menemukan bahwa dampak investasi asing langsung di Venezuela terhadap produktivitas ekonomi sangatlah kecil (Effendi dan Soemantri, 2003).Temuan ini serupa dengan hasil kajian yang dilakukan oleh Germidis (1997), Hasil kajian empiris ini berbeda dengan temuan yang diperoleh Borensztein, Gregorio dan Lee (1998) serta Effendi dan Soemantri (2003) yang menyatakan bahwa investasi asing langsung justru meningkatkan pertumbuhan ekonomi. Temuan ini didukung oleh Alfaro, Chandra Kelemli-Ozcan dan Sayek (2000) yang juga menyatakan bahwa kehadiran investasi asing langsung berdampak positip terhadap pertumbuhan ekonomi, terutama dalam sektor keuangan.

Penanaman Modal Dalam Negeri adalah kegiatan menanam modal untuk melakukan usaha di wilayah Negara Republik Indonesia yang dilakukan oleh penanam modal dalam negeri dengan menggunakan modal dalam negari. Investasi disini ialah bahwa masyarakat tidak menggunakan semua pendapatannya untuk dikonsumsi, melainkan ada sebagian yang ditabung dan tabungan ini diperlukan untuk pembentukan investasi. Selanjutnya pembentukan investasi ini telah dipandang sebagai salah satu faktor bahkan faktor utama di dalam pembangunan ekonomi. Misalkan, investasi dalam peralatan modal atau pembentukan modal adalah tidak hanya meningkatkan produksi atau pertumbuhan ekonomi, tetapi juga dapat meberikan kesempatan kerja bagi masyarakat. Dengan demikian terdapat hubungan yang positif antara pembentukan investasi dengan pertumbuhan ekonomi pada suatu negara (Prasetyo, 2009).

Untuk meningkatkan pertumbuhan ekonomi diperlukan investasi-investasi baru sebagai stok modal. Investasi dapat dilakukan oleh swasta berupa investasi PMDN dan PMA lalu pengeluaran pemerintah berupa belanja modal, belanja barang dan jasa atau kerjasama antara pemerintah dan swasta. Berdasarkan Tabel 3 diabawah ini nilai Investasi dengan kecenderungan (trend) yang meningkat baik PMA maupun PMDN.

Tabel 3

Jumlah Investasi Provinsi Jambi Tahun (2004-2015)

\begin{tabular}{crrr}
\hline Tahun & PMDN (juta Rp) & PMA (juta Rp) & \multicolumn{1}{c}{ Total (juta Rp) } \\
\hline 2004 & 8.534 .189 & $667.445,71$ & $9.201 .634,71$ \\
2005 & 8.788 .967 & $730.529,92$ & $9.519 .496,92$ \\
2006 & 9.128 .009 & $1.170 .499,92$ & $10.2985005,92$ \\
2007 & 9.193 .509 & $1.171 .456,29$ & $10.364 .965,29$ \\
2008 & 8.838 .272 & $1.982 .287,47$ & $10.820 .559,47$ \\
2009 & 8.048 .826 & $1.817 .216,28$ & $9.866 .042,28$ \\
2010 & 9.611 .608 & $2.005 .272,45$ & $11.616880,45$ \\
2011 & 14.433 .096 & $4.764 .402,38$ & $19.197 .498,38$ \\
2012 & 19.933 .675 & $7.450 .686,72$ & 27.384 .361 .72 \\
2013 & 25.170 .00 & $9.155 .386,30$ & $34.325 .386,30$ \\
2014 & 28.418 .185 & $11.525 .838,66$ & $39.944 .023,66$ \\
2015 & 31.997 .000 & $14.889 .838,66$ & $46.886 .838,66$ \\
\hline
\end{tabular}

Sumber: BPS Provinsi Jambi, Tahun 2016 


\section{Hubungan antara Tenaga Kerja dengan Pertumbuhan Ekonomi}

Todaro (2000), pertumbuhan penduduk dan pertumbuhan Angkatan Kerja (AK) secara tradisional dianggap sebagai salah satu faktor positif yang memacu pertumbuhan ekonomi. Jumlah tenaga kerja yang lebih besar berarti akan menambah tingkat produksi, sedangkan pertumbuhan penduduk yang lebih besar berarti ukuran pasar domestiknya lebih besar. Boediono (1992) menjelaskan bentuk umum fungsi produksi antara kapital (K) dan tenaga kerja (L) adalah sebagai berikut : $\mathrm{Q}=\mathrm{f}(\mathrm{K}, \mathrm{L})$; dimana : $\mathrm{Q}=$ output $\mathrm{K}=$ stok kapital $\mathrm{L}=$ tenaga kerja. Persamaan diatas menunjukan bahwa stok kapital dan tenaga kerja dapat meningkatkan output. Apabila output meningkat pada periode tertentu, maka sebagian kenaikan output akan diinvestasikan sehingga stok kapital akan bertambah besar sebesar output yang diinvestasikan. Untuk tenaga kerja menandakan adanya penciptaan kesempatan tenaga kerja akibat dari peningkatan output tersebut. Kesempatan kerja dapat diartikan sebagai partisipasi dalam pembangunan, baik dalam arti memikul beban pembangunan maupun dalam tanggung jawab atas pelaksanaan pembangunan ataupun didalam menerima kembali hasil pembangunan tersebut (Tumangkeng, 2011).

Menurut Deddy (2008:96) bahwa Angkatan Kerja berpengaruh secara signifikan terhadap pertumbuhan ekonomi. Jumlah tenaga kerja yang lebih besar berarti akan menambah tingkat produksi, sedangkan pertumbuhan penduduk yang lebih besar berarti ukuran pasar domestiknya lebih besar. Selanjutnya dikatakan bahwa pengaruh positif atau negatif dari pertumbuhan penduduk tergantung pada kemampuan system perekonomian daerah tersebut dalam menyerap dan secara produktif memanfaatkan pertambahan tenaga kerja tersebut menurut Todaro dalam Suryanto (2011:29). Dengan demikian dapat dikatakan bahwa salah satu faktor berpengaruh terhadap pertumbuhan ekonomi adalah tenaga kerja (Adisasmita 2013:106).

Tenaga kerja adalah penduduk dalam usia kerja (berusia 15 - 64 tahun) atau jumlah seluruh penduduk dalam suatu negara yang dapat memproduksi barang dan jasa jika ada permintaan terhadap tenaga mereka, dan jika mereka mau berpartisipasi dalam aktivitas tersebut (Mulyadi, 2003:57). Badan Pusat Statistik (BPS), Tenaga Kerja adalah setiap orang yang mampu melakukan pekerjaan guna menghasilkan barang dan atau jasa baik untuk memenuhi kebutuhan sendiri maupun untuk masyarakat. Batas usia kerja yang dianut oleh Indonesia adalah minimum 10 tahun, tanpa batas umur maksimum, Jadi setiap setiap orang atau penduduk yang sudah berusia 10 tahun keatas, tergolong sebagai tenaga kerja.

Tenaga kerja (man power) terdiri atas dua kelompok yaitu angkatan kerja (labour force) dan bukan angkatan kerja. Angkatan kerja (labor force) adalah tenaga kerja atau penduduk dalam usia kerja yang bekerja, atau mempunyai pekerjaan namun untuk sementara tidak bekerja, dan yang mencari pekerjan. Sedangkan Bukan Angkatan Kerja (unlabour force) adalah tenaga kerja atau penduduk dalam usia kerja yang tidak bekerja, tidak mempunyai pekerjaan dan sedang tidak mencari pekerjaan, yakni orang-orang yang kegiatanya bersekolah (pelajar, mahasiswa), mengurus rumah tangga (maksudnya ibu-ibu yang bukan wanita karir), serta menerima pendapatan tapi bukan merupakan imbalan langsung atas jasa kerjanya (Dumairy, 1996:74-75). 25

Untuk mengetahui lebih jelasnya jumlah Angkatan Kerja di Provinsi Jambi dapat dilihat pada Tabel 4 
Tabel 4

Perkembangan Tenaga Kerja di Provinsi Jambi Tahun 2004-2015

\begin{tabular}{crr}
\hline \multirow{2}{*}{ Tahun } & \multicolumn{2}{c}{ Jumlah Angkatan Kerja } \\
& Tenaga Kerja (Jiwa) & Perkembangan \% \\
\hline 2004 & 1.210 .568 & - \\
2005 & 1.247 .114 & 3,02 \\
2006 & 1.181 .650 & $-5,25$ \\
2007 & 1.222 .951 & 3,50 \\
2008 & 1.290 .854 & 5,55 \\
2009 & 1.334 .496 & 3,38 \\
2010 & 1 '432.814 & 7,37 \\
2011 & 1.495 .167 & 4,35 \\
2012 & 1.470 .920 & $-1,62$ \\
2013 & 1.452 .832 & $-1,23$ \\
2014 & 1.570 .882 & 8,13 \\
2015 & 1.620 .012 & 3,17 \\
Rata-Rata & & $\mathbf{2 , 7 6}$
\end{tabular}

Sumber : BPS Provinsi Jambi Tahun 2016

\section{Analisi Regresi}

Analisis regresi linear beraganda adalah hubungan secara linear antara dua atau lebih variabel independen (X) dengan variabel dependen (Y).Analisis ini untuk mengetahui arah hubungan antara variabel independen dengan variabel dependen apakah positif atau negatif dan untuk memprediksi nilai dari variabe dependen apabila independen mengalami kenaikan atau penurunan. Berikut hasil uji regresi dengan menggunakan program EViews 8.

Tabel 5

Hasil Regresi Linear Berganda

\begin{tabular}{lrrrr}
\hline \hline \multicolumn{1}{c}{ Variable } & Coefficient & Std. Error & t-Statistic & Prob. \\
\hline \hline C & 1.762689 & 1.730800 & 1.018424 & 0.3424 \\
LOG(PP) & 0.264658 & 0.047131 & 5.615393 & 0.0008 \\
LOG(PMA) & -0.008618 & 0.040143 & -0.214675 & 0.8361 \\
LOG(PMDN) & 0.013761 & 0.031954 & 0.430649 & 0.6797 \\
$\quad$ LOG(TK) & 0.780053 & 0.119218 & 6.543057 & 0.0003 \\
\hline \hline R-squared & 0.997355 & Mean dependent var & 16.64704 \\
Adjusted R-squared & 0.995843 & S.D. dependent var & 0.238949 \\
S.E. of regression & 0.015406 & Akaike info criterion & -5.213821 \\
Sum squared resid & 0.001661 & Schwarz criterion & -5.011777 \\
Log likelihood & 36.28293 & Hannan-Quinn criter. & -5.288625 \\
F-statistic & 659.8258 & Durbin-Watson stat & 2.582204 \\
Prob(F-statistic) & 0.000000 & & & \\
\hline \hline
\end{tabular}

Sumber: data olahan 
Hasil regresi pada Tabel 5 diperoleh persamaan regresi sebagai berikut:

$\mathrm{PE}=1,762689+0,264658$ LOG(PP) - 0,008618LOG(PMA) + 0,013761LOG(PMDN) + 0,780053LOG(TK)

Persamaan regresi diatas secara keseluruhan bahwa nilai koefisien $\beta_{\mathrm{o}}$ sebesar 1,7626 artinya, apabila selama tahun 2004 sampai 2015 tidak terjadi perubahan variabel Pengeluaran Pemerintah (PP), investasi PMDN, investasi PMA, jumlah Tenaga Kerja (TK) tidak mengalami perubahan atau dengan asumsi konstan, maka angka Pertumbuhan Ekonomi (PE)) untuk Provinsi Jambi akan mengalami peningkatan sebesar 1,17626. Meningkatnya angka Pertumbuhan Ekonomi bisa terjadi, diakibatkan faktor lain di luar variabel dalam penelitian ini. Sedangkan koefisien regresi variabel Pengeluaran Pemerintah (PP), $\left(\beta_{1}\right)$ diperoleh nilai sebesar 0,2646, artinya apabila terjadi kenaikan atau peningkatan Pengeluaran Pemerintah (PP) sebesar 1 persen, maka akan menaikan angka Pertumbuhan Ekonomi (PE) untuk Provinsi Jambi sebesar 0,2646 persen dengan asumsi bahwa variabel lain tetap (Cateris paribus) atau tidak terjadi perubahan atau konstan. Hasil regresi untuk koefisien Pengeluaran Pemerintah tersebut, menggambarkan bahwa kondisi dan Pengeluran Pemerintah terhadap kenaikan angka Pertumbuhan Ekonomi Provinsi Jambi masih rendah. Kondisi demikian perlu menjadi perhatian pemerintah daerah kedepannya untuk mengambil kebijakan yang tepat dan efektif agar Pengeluaran Pemerintah dapat memacu pertumbuhan ekonomi berpengaruh besar terhadap peningkatan tarap hidup masyarakat Provinsi Jambi.

Untuk koefisien regresi variabel Penanaman Modal Asing (PMA) diperoleh nilai Koefisien ( $\beta 2$ ), sebesar $-0,0086$ artinya apabila terjadi kenaikan atau peningkatan investasi PMA sebesar 1 persen, maka akan menurunkan angka Pertumbuhan Ekonomi Provinsi Jambi (PE) sebesar 0,0086 persen dengan asumsi bahwa variabel lain tetap (Cateris paribus) atau tidak terjadi perubahan atau konstan. Penelitian ini sejalan dengan temuan Hadad dan Harison (1993) yang menyatakan bahwa investasi asing langsung tidak memiliki pengaruh yang signifikan terhadap peningkatan pertumbuhan ekonomi. Koefisien ( $\beta 3$ ) diperoleh nilai sebesar $\mathbf{0 , 0 1 3 7 6 1}$, artinya apabila terjadi kenaikan atau peningkatan investasi Penanaman Modal Dalam Negeri (PMDN) sebesar 1 persen, maka akan meningkatkan angka Pertumbuhan Ekonomi (PE) Provinsi Jambi sebesar 0,013761 dengan asumsi bahwa variabel lain tetap (Cateris paribus) atau tidak terjadi perubahan atau konstan. Berdasarkan hasil estimasi untuk variabel investasi PMDN belum optimal walaupun berpengaruh positif tapi tidak signifikan dalam manaikan Pertumbuhan Ekonomi, hal ini dimungkinkan karena Investasi PMDN belum menyerap Tenaga kerja optimal, dan tidak selalu diikuti oleh Kemajuan Teknologi sehingga Produktiftivitas belum berdampak pada peningkatan pendapat yang layak dan peningkatan daya beli masyarakat. Untuk koefisien regresi variabel $\left(\beta_{4}\right)$ diperoleh nilai sebesar $\mathbf{0 , 7 8 0 0 5 3}$, artinya apabila terjadi kenaikan atau peningkatan Tenaga Kerja (TK)) sebesar 1 persen, maka akan menaikan angka Pertumbuhan Ekonomi (PE) Provinsi Jambi sebesar $\mathbf{0 , 7 8 0 0 5 3}$ dengan asumsi bahwa variabel lain tetap (Cateris paribus) atau tidak terjadi perubahan atau konstan. Hasil estimasi ini menunjukkan bahwa jumlah Tenaga Kerja (TK) dapat mempengaruhi tinggi rendahnya angka Pertumbuhan Ekonomi Provinsi Jambi. Dalam hal ini jumlah Tenaga Kerja (TK) di Provinsi Jambi cenderung dapat meningkatkan angka Pertumbuhan Ekonomi (PE). Namun 
Pembangunan Provinsi Jambi yang masih tahap perkembangan, tentu perlu upaya memenuhi sumber daya manusia yang berkualitas sebagai modal pembangunan, penyerapan tenaga kerja banyak di sektor informal dibandingkan sektor formal ini disebabkan tingkat keterampilan relatif masih renda.

\section{Uji Asumsi Klasik}

\section{Uji Multikolinearitas}

Salah satu cara mendeteksi apakah terjadi multikolinearitas atau tidak di dalam model, dapat dilihat R- Squared yang dihasilkan oleh estimasi tinggi yaitu 0,997355 dan secara individu salah satu variabel independen signifikan terhadap dependen maka tidak terjadi multikolinearitas dalam persamaan ini. Cara lain yang digunakan untuk mendeteksi ada atau tidak multikolinearitas di dalam model adalah dengan melihat matriks koefisien korelasi. Jika terdapat variabel yang memiliki nilai korelasi mendekati 1, maka model teridentifikasi multikolinearitas sempurna, sedangkan jika tidak terjadi multikolinearitas sempurna, maka model bisa digunakan untuk estimasi. Hasil uji multikolinearitas ini dapat dinyatakan secara keseluruhan tidak terdapat penyimpangan asumsi klasik dan dinyatakan lolos uji multikolinearitas.

\section{Uji Autokorelasi}

Pengujian fenomena autokorelasi dalam penelitian ini menggunakan uji Durbin-Watson. Berdasarkan pada pengujian Durbin-Watson diketahui bahwa persamaan tersebut bebas dari autokorelasi. Nilai DW hitung (2.582204) terletak diantara $\mathrm{d}_{\mathrm{U}}(2,46)$ dan 4-du $(4-2,90=2.582204)$ yaitu di wilayah bebas autokorelasi dan wilayah tidak dapat diputuskan. Pada hasil perhitungan uji DW tersebut masih berada wilayah bebas autokorelasi sehingga dapat dikatakan bahwa persamaan regresi diatas lolos uji asumsi klasik autokorelasi.

\section{Uji Heteroskedastisitas}

Uji Park dapat digunakan untuk menguji ada tidaknya heteroskedastisitas dalam model yang digunakan, hasil pengujian adalah sebagai berikut : Berdasarkan pada uji Park, suatu model dianggap bebas heteroskedastisitas jika nilai probabilitas t-statistik lebih besar dari $\alpha=(5 \%)$. Sehingga dapat dikatakan bahwa persamaan regresi ini tidak terindikasi gejala heteroskedastisitas bila dilakukan secara simultan dimana F-hitungnya lebih besar dari F-prob.

\section{Uji t}

Berdasarkan uji statistik parsial dengan tingkat keyakinan $\alpha=5 \%$, diperoleh nilai t-statistik untuk variabel PP $\left(\beta_{1}\right)$ yang nilainya lebih besar dari tprob $(5,61539>0,0008)$, artinya $\mathrm{H}_{0}$ ditolak $\mathrm{H}_{1}$ diterima. Hal ini menunjukkan bahwa Pengeluaran Pemerintah (PP) selama periode 2004 sampai dengan 2015 berpengaruh signifikan terhadap Pertumbuhan Ekonomi (PE)) di Provinsi Jambi pada tingkat keyakinan $\alpha$ diatas 5 persen. Ini berarti Pengeluaran Pemerintah berpengaruh positif dan signifikan, efekttif dalam meningkatkanPertumbuhan Ekonomi (PE) di Provinsi Jambi.

Temuan nilai t-statistik untuk variabel PMA, $\left(\beta_{2}\right)$ diperoleh nilai yang lebih kecil dari t-prob $(0,214675<0,7390)$, artinya $\mathrm{H}_{0}$ diterima $\mathrm{H}_{1}$ ditolak. Artinya bahwa Investasi PMA tidak berpengaruh signifikan terhadap Pertumbuhan Ekonomi (PE) Provinsi Jambi pada tingkat keyakinan $\alpha$ diatas 5 persen. Hal ini 
dikarenakan banyak PMA berjangka pendek, penyerapan tenaga kerja yang relatif kecil. Untuk itu perlu upaya untuk meningkatkan kualitas keterampilan atau keahlian khusus bagi Tenaga Kerja sehingga bisa masuk disektor formal dan Perusahaan Asing.

Sedangkan untuk nilai t-statistik untuk variabel PMDN, $(\beta 3)$ diperoleh nilai yang lebih kecil dari t-prob $(0,430649<0,67997)$, artinya $\mathrm{H}_{0}$ diterima $\mathrm{H}_{1}$ tolak. Ini menunjukan bahwa investaasi PMDN berpengaruh positif tetapi tidak signifikan terhadap Pertumbuhan Ekonomi (PE) Provinsi Jambi pada tingkat keyakinan $\alpha$ dibawah 5 persen. Hal ini investasi PMDN belum dioptimalkan untuk membangkitkan penyerapan tenaga kerja, dan belum efektif dan efesienya Pengelolaan PMDN sehingga belum optimalnya peningkatan Pertubuhan Ekonomi. Maka dari itu perlu kebijakan yang tepat dimana investasi PMDN disamping berpengaruh positif terhadap Pertumbuhan Ekonomi tetapi juga harus ada alih teknologi sehingga produk atau jasa yang dihasilkan dapat berdaya guna dan mampu meningkatkan daya saing daerah.

Untuk nilai t-statistik untuk variabel Tenaga Kerja (TK) $\left(\beta_{4}\right)$ diperoleh nilai yang lebih tinggi dari t-prob $(6,54330>0,00030)$, artinya $\mathrm{H}_{0}$ ditolak $\mathrm{H}_{1}$ diterimah. Artinya bahwa jumlah Tenaga Kerja(TK) berpengaruh positif dan signifikan terhadap Pertumbuhan Ekonomi pada tingkat keyakinan $\alpha$ diatas 5 persen. Hal ini berarti jika Tenaga Kerja dapat bekerja, maka pendapatan meningkat, daya beli masyarakat meningkat dan pada gilirannya angka pertumbuhan ekonomi akan meningkat dan berkualitas.

\section{Uji F}

Berdasarkan persamaan diatas, diperoleh nilai F-statistiknya lebih besar dari nilai F-prob $(659,8258>0,00000)$ pada tingkat keyakinan $\alpha=5 \%$. Artinya, $\mathrm{H}_{0}$ ditolak dan $\mathrm{H}_{1}$ diterima. Ini menunjukan bahwa secara bersama-sama variabel Pengeluaran Pemerintah (PE)), investasi PMA, investasi PMDN, jumlah Tenaga Kerja (TK) berpengaruh signifikan terhadap naik turunnya Pertumbuhan Ekonomi (PE) di Provinsi Jambi selama periode 2004- 2015).

\section{Tingkat Signifikansi R-Squared $\left(R^{2}\right)$}

Hasil perhitungan R- squared yang ditunjukkan pada persamaan diatas diperoleh nilai $\mathrm{R}^{2}$ sebesar 0,997355 . Hal ini menunjukan bahwa sekitar 99,7355 persen naik turunnya angka Pertumbuhan Ekonomi (PE) di Provinsi Jambi dipengaruhi oleh variabel ; Pengeluaran Pemerintah, investasi PMA, investasi PMDN, dan jumlah Tenaga Kerja. Sedangkan sisanya 0,2645persen, dijelaskan oleh variabel lain yang tidak dimasukan kedalam persamaan regresi.

\section{Implikasi}

Berdasarkan hasil persamaan regresi linear berganda dengan uji t dan uji $\mathrm{F}$ dapat diketahui bahwa Pertumbuhan Ekonomi yang merupakan sumber keberhasilan pemerintah dalam menjalankan roda pemerintahan sangat di pengaruhi oleh Tenaga Kerja, Pengeluaran Pemerintah, Penanaman Modal Dalam Negeri. Sementara variabel Penanaman Modal Asing kurang memberi dampak. Terjadinya hasil Penelitian ini PMA tidak berdampak positif terhadap pertumbuhan ekonomi di Provinsi Jambi periode 2004-2015 dimungkinkan Penanaman Modal Asing terfokus pada sektor-sektor berteknologi tinggi sehingga tidak dapat menyerap tenaga kerja lokal. 
Pertumbuhan ekonomi juga harus dibarengi peningkatan daya saing daerah. Terutama pada peningkatan investasi yang dimiliki untuk pembangunan pada sektor-sektor yang produktif di daerah dan memakai Teknologi Tepat guna sehingga dapat menyerap Tenaga Kerja lokal. Sebagai konsekuensi, Pemerintah Provinsi Jambi tidak hanya berorientasi peningkatan investor yang bergerak pada paadat modal dan padat teknologi akan tetapi lebih kepada padat karya agar penyeraparan Tenaga Kerja lokal optimal sehingga kesejahteran masyarakat dapat terwujud. Untuk itu pemerintah Provinsi Jambi perlu memiliki kebijakan sendiri yang berpihak kepada masyarakat sehingga pertumbuhan ekonomi akan berdampak positif dan pembangunan menjadi lebih berkualitas.

\section{SIMPULAN}

Berdasarkan hasil penelitian dan pembahasan yang dilakukan untuk menganalisa pengaruh Pengeluran Pemerintah, investasi PMA, investasi PMDN, dan Tenaga Kerja terhadap Pertumbuhan Ekonomi di Provinsi Jambi pada tahun 2010-2015 maka dapat disimpulkan:

1. Tenaga Kerja, dan Pengeluaran Pemerintah berpengaruh positip dan signifikan dalam meningkatkan pertumbuhan ekonomi di Provinsi Jambi.

2. Penanaman Modal Dalam Negeri berpengaruh positif tetapi tidak signifikan terhadap Pertumbuhan Ekonomi Provinsi Jambi, sedangkan Penanaman Modal Asing tidak berpengaruh positif dan tidak singnifikan terhadap pertumbuhan ekonomi Provinsi Jambi.

\section{DAFTAR PUSTAKA}

Adisasmita, Rahardjo. 2013.Teori-teori Pembangunan Ekonomi. Yogyakarta: Graha Ilmu

Arsyad, L. 2010. Ekonomi Pembangunan. Edisi kelima. UPP STIM YKPN, Yogyakarta

Bambang Muqsyithu Wihda, Dwisetia Poerwono. Analisis Pengaruh PMDN, PMA, Pengeluaran Pemerintah dan Tenaga Kerja terhadap Pertumbuhan Ekonomi. Journal of Economics. Volume 3, Nomor 1, Tahun 2014, Halaman 3 http://ejournal-s1.undip.ac.id/index.php/jme ISSN (Online): 2337-3814

Dumairy. 2001. Perekonomian Indonesia, Jakarta :Erlangga

Erwin B.Karnadi. 2016. Panduan EViews Untuk Ekonometrika Dasar. Jakarta PT.Gramedia Widiasarana

Eddy Soegiarto dan Mardyono. Pengantar Teori Ekonomi: Ekonomi Mikro Ekonomi Makro,Cetakan Pertama (Tanggerang Selatan:Mahkota Ilmu, 2011), 110.

Gujarati, Damodar. 2003. Ekonometri Dasar. Terjemahan: Sumarno Zain, Erlangga: Jakarta.

Hasan, M. Iqbal. 2002. Pokok-pokok Materi Metodologi Penelitian dan Aplikasinya,. Ghalia Indonesia, Bogor.

Mangkoesoebroto, Guritno. 2013. Ekonomi Publik,. Edisi Ketiga. BPFE: Yogyakarta

Muana, Nanga. 2005. Makro Ekonomi, Masalah dan Kebijakan,. PT. Raja Grafindo Persada: Jakarta

Mankiw, Gregory. 2006. Pengantar Ekonomi Makro Edisi Ketiga. Jakarta: Salemba Empat. 
Sukirno, Sadono. 2004. Makroekonomi: Teori Pengantar. Jakarta : PT Raja Grafindo Pustaka.

Sumodiningrat, Gunawan.1994. Ekonomi Produksi. Yogyakarta : Gajahmada University Press.

Prasetyo, Eko.2009. Fundamental Ekonomi Makro. Yogyakarta: Beta Offset

Todaro, Michael, P. dan Stephen C. Smith. 2004 . Pembangunan Ekonomi di Dunia Ketiga, edisi kedelapan. Jakarta : Erlangga.

Todaro, Michael P. dan Smith, Stephen C. 2006. Pembangunan Ekonomi. Jakarta: Erlangga.

Wing Wahyu Winarno.2009.Analisa Ekonometrik dan Statistika dengan EViews. UPP STIM YKPN,Yogyakarta.

Widarjono, Agus. 2009. Ekonometrika pengantar dan aplikasinya. Yogyakarta : Ekonisia. 